\title{
CLASSIFICATION OF THE GALL-WASPS AND THE PARASITIC CYNIPOIDS, OR THE SUPERFAMILY CYNIPOIDEA. IV.
}

By William H. ASHMEAD, A. M., SC. D., ASSistant CURAToR, v. S. National MUSEUM.

TRIBE II. - RHODITINI.

The members of this tribe form galls only on the Roseworts (Rosaceae), and apparently, so far as the records go, will attack no other order of plants, the rose (Rosa) and the bramble (Rubus) especially being subject to their attacks; they show some affinity with the Aulacini, some of which also form galls on the Rosaceae, but these latter are easily distinguished by the venation of the front wings and by abdominal differences, the hypopygium not being prominent or acutely pointed as in the former, while the second segment is usually much shorter.

Walsh, deceived by the statement of a farmer, described his genus Tribalia as forming galls on the potato Solanum tuberosum, but these turn out to be rootgalls on rose, closely resembling a potato. The genus is very closely allied to Rhodites Hartig and has been rechristened recently by Abbé Kieffer under the name of Lytorhodites.

\section{Table of Genera.}

r. Front wings with the marginal cell open along the front margin . $\quad 2$ Front wings with the marginal cell completely closed . . . . 3

2. Mesonotum usually subopaque, finely punctured or coriaceous, with distinct parapsidal furrows, the middle lobe usually with a median impressed line posteriorly; scutellum rugulose, without distinct foveae at base; antennae I 4 -jointed in both sexes, the third joint in the $\approx$ not longer than the $4^{\text {th }}$ and $5^{\text {th united }}$

Tribalia Walsh = Lytorhodites Kieffer (Type T. batatorum Walsh.)

3. Antennae I4-jointed in both sexes, the third joint very long, subclavate, in $\delta$ longer than the $4^{\text {th }}$ and $5^{\text {th }}$ united . . . . Rhodites Hartig (Type Cynips rosae Linné.)

\section{TRIBE III.- PediaspidinI.}

This tribe is probably the smallest known or at least not many species have as yet been discovered, and these confine their attacks to the Mapleworts (Sapindaceae). 
No species is yet known from America, but a more careful search for galls on our numerous species of maples will probably show that we have representatives.

The European species form galls on the leaves of Acer pseudoplatanus L. and fall into a single genus, which may be recognized by the following characters :-

Marginal cell open along the front margin, the first abscissa of the radius angulated or sub-angulated, the areolet distinct; thorax smooth, shining, with distinct, complete parapsidal furrows; scutellum somewhat elevated on the disk and higher than the mesonotum, the elevated disk is flat or has a slight median depression, either smooth or punctate; antennae in agamous 9 I 5or 16 -jointed, in sexual form 14 -jointed in $q$ and 15 -jointed in $\delta$, the third joint scarcely as long as the scape and pedicel united, but longer than the fourth

Pediaspis Tischbein

= Bathyaspis Förster

(Type P. sorbi T'ischb.)

Tribe IV.-Aulacini.

At present this tribe is not well represented in genera and species, but probably will be found to be fully as large as the tribe Cynipini, since its known members attack several orders of plants and it necessarily follows that there must be many genera and species still discoverable.

The known species form galls on the Roseworts (Rosaceae), the Poppyworts (Papaveraceae), the Crucifers (Cruciferaceae), the Mallows (Malvaceae), the Sumacs (Anacardiaceae), the Asterworts (Compositaceae), the Heathworts (Ericaceae), and the Figworts (Scrophulariaceae).

Sixteen genera are already known which may be recognized by the use of the following table:-

\section{Table of Genera.}

I. Marginal cell closed along the front margin Marginal cell open along the front margin.

First abscissa of the radius curved, the apical branch of the subcostal vein straight; parapsidal furrows sharply defined, complete; antennae in 9 I 3-14-jointed, the third joint shorter than the fourth or no longer, in $\delta$ I 4-jointed. . . . . . . . . Aulacidea Ashmead

(Type Aulax mulgidiicola Ashm.)

First abscissa of the radius almost straight, the apical branch of the subcostal vein curved; parapsidal furrows incomplete or vaguely, indis- 
tinctly defined posteriorly; antennae in $q \mathrm{r} 3$-jointed, the third joint longer than the fourth, in $\delta$ I 5 -jointed. Phanacis Förster (Type P. centaureae Först.)

3. Areolet in front wings entirely absent, or at most with only one side present .

Areolet in front wings distinct, triangular.

Areolet not lying directly beneath the origin of the radius . $\quad 5$ Areolet lying directly beneath the origin of the radius or at least its base is on a line with the origin of the radius.

Scutellum at base distinctly bifoveated, the foveae separated by a carina . . . . . . . . . . 4

Scutellum at base without foveae, but with a transverse furrow, the bottom of the furrow being finely streaked.

'Thorax coriaceous, with indistinct parapsidal furrows; areolet very delicate, nearly obsolete; antennae in $q$

Solenozopheria Ashmead (Type S. vaccinii Ashm.)

4. Scutellum in outline conical or pyramidal; mesopleura on lower half coarsely sculptured, the disk with some striae; antennae in $\$$ I3-jointed, the third joint distinctly longer than the fourth, in $\delta$ I 4-jointed Gonaspis Ashmead (Type Diastrophus scutellaris Gillette.)

Scutellum normal, rounded or obtuse behind, never conical or pyramidal; mesonotum smooth, not longitudinally striated, the parapsidal furrows distinct; antennae in $q \mathrm{I} 4$-jointed, in $\delta \mathrm{I} 5$-jointed.

Diastrophus Hartig

(Type D. rubii Hartig.)

5. Mesonotum perfectly smooth and shining, with the parapsidal furrows distinct, or at least sharply defined posteriorly . . . . . . . . 6 Mesonotum not perfectly smooth and shining, shagreened, coriaceous, finely

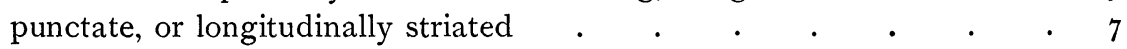

6. Antennae in ${ }^{\prime} \mathrm{r}_{3}$-jointed, in $\delta \mathrm{I}_{5}$-jointed, the third joint not longer than the fourth; scutellum rugulose; metathoracic carinae absent Xestophanes Förster . . . . . . (Type Cynips potentillae Retzius.)

Antennae in $q$ and $\delta$ I4-jointed, the third joint a little longer than the fourth; scutellum almost smooth; metathorax with two parallel, widely separated carinae. . . . . . . . Gillettea Ashmead (Type G. taraxaci Ashm.)

7. Mesonotum not longitudinally striated, either shagreened, coriaceous, or very closely finely punctate, with the parapsidal furrows distinct . $\quad$. 8 Mesonotum longitudinally striated, with the parapsidal furrows very short and indistinct. 
Antennae in $\&$ r 4 -jointed ( $\delta$ unknown), the second joint longer than the third, the latter longer than the fourth; claws finely denticulate Pantelliella Kieffer (Type P. fedtschenkoi Kieffer.)

8. Head oblong, longer than wide Head normal, transverse.

Foveae at base of scutellum of moderate size, neither large, triangular, nor deep . . . . . . . . . . . . . . . 9

Foveae at base of scutellum large, deep, and triangular, extending to the middle of the scutellum.

Antennae in $q$ r 3 -jointed, the third joint somewhat shorter than the fourth, in $\delta$ I 4 -jointed, filiform, the third joint shorter than the fourth

Isocolus Förster = Eubothrus Förster

(Type Diastrophus scabiosus.)

9. Antennae in $\&$ I 3 -jointed, the third joint distinctly shorter than the fourth, in $\delta$ I 5 -jointed, filiform, the third joint a little longer than the fourth

Pseudaulax Ashm. gen. nov.

(Type Cynips hieracii Löw.)

Antennae in $\$$ I 4--jointed, the third joint usually as long as the fourth, in 8 15-jointed, the third joint not longer than the fourth . Aulax Hartig

(Type Cynips rhoeados Bouché.)

ro. Antennae in $\&$ I 3 -jointed ( $\delta$ unknown); scutellum ovate, tuberculate

Cecconia Kieffer

(Type Aulax valerianellae Thomson.)

I I. First abscissa of the radius straight, or very nearly, not angulated or curved; mesonotum coarsely coriaceous or shagreened, opaque; head bulging out behind the eyes, the cheeks longer than the eyes . . . . . I2

First abscissa of the radius curved or subangulated; mesonotum smooth, shining, or at the most alutaceous; head not bulging out behind the eyes, the cheeks shorter than the eyes.

Antennae in $\$ 13$ or 14 -jointed, the third joint not shorter than the fourth, usually a little longer, in $\delta$ r 4 -jointed . . . Liposthenus Förster

(Type Aulax glechomae Hartig.)

12. Middle mesothoracic lobe with a distinct median grooved line its entire length or only vaguely defined anteriorly; foveae at base of scutellum not very distinct ; third joint of antennae much longer than the fourth . . 13 Middle mesothoracic lobe without such a grooved line, at the most with only a short grooved median line posteriorly; foveae at base of scutellum distinct; third joint of antennae shorter than the fourth. 
Antennae in $q$ r 4-jointed, the third joint shorter than the fourth, in $\delta$ I 5 -jointed; second abdominal segment not occupying much more than half the length of the whole surface of abdomen Antistrophus Walsh

(Type A. pisum Walsh.)

Antennae in $q$ I 3 -jointed, the third joint much shorter than the fourth, in $\delta$ I 4 -jointed, the fourth joint much longer than the third; second abdominal segment occupying fully two thirds the whole surface of the abdomen dorsally, but ventrally it is much shorter Asclepiadiphila Ashmead . . . . . (Type A. stephanotidis Ashm.)

13. Antennae in $\$$ r4-jointed, the third joint very long, nearly twice as long as the second; second abdominal segment large, occupying about four fifths the whole surface of the abdomen

Timaspis Mayr (Type T. phaenixopodos Mayr.)

\section{Tribe V.- Eschatocerini.}

The members of this tribe attack plants belonging to the order Leguminoseae. Not many species are known and these fall into a single genus, Eschatocerus Mayr, described from South America. I have, however, an undescribed species from California and I suspect when our sensitive plants, milk-vetches and our many other leguminous plants are carefully examined for galls, many other genera and species will be discovered.

The tribe is easily separated from the others by the antennae being inserted high up on the face above an imaginary line drawn from the apex of the eyes, and by peculiarities of venation. The single genus may be characterized as follows :-

Front wings with a callosity at the union of the basal nervure with the median vein and another along the first abscissa of the radius, the areolet being obliterated and the cubitus originating from this callosity; hypopygium plow-share shaped, without a prominent spine; antennae in $\$$ i 3 -jointed, the third joint about equal to the fourth, in $\delta$ r 4 -jointed, the third joint a little longer than the fourth . . . . Eschatocerus Mayr (Type E. acaciae Mayr.)

\section{Subfamily III._- Ibaliinae.}

This group is quite distinct from all others in the venation of the front wings, in having the abdomen long and very strongly compressed, cultriform or knife shaped, and in the totally different shape of the legs, the hind tibiae being very long, longitudinally furrowed, with two apical spurs, while the basal joint of the 
hind tarsi is somewhat thickened and abnormally lengthened, being nearly twice as long as joints 2-5 united. It shows some affinity with the Figitidae, and particularly with the subfamily Liopterinae, and may yet be classified with that family, its members being genuine parasites, but with quite different hosts from those of the Figitides. In Europe, Mr. André has bred Ibalia leucospoides Hochenwarth from a Horn-tail, Sirex gigas L., while in America, Mr. W. Hague Harrington has ascertained that Ibalia maculipennis destroys the larvae of Tremex columba L. and Xiphydria albicornis Harris. In the Riley Collection is a single specimen of Ibalia maculipennis labeled, "So. Ill. bred from Hickorywood, June 4th, I875," so that probably the group attacks any member of the superfamily Siricoidea, and is therefore of great economic importance.

The single genus known may be recognized by the following characters :-

Thorax coarsely, transversely rugulose; front wings with the marginal cell long, narrow lanceolate and usually closed ; antennae in 9 r 3 -jointed, filiform, in $\delta$ r 4 -jointed, the third joint excised beyond the middle . Ibalia Latreille (Type Ichneumon leucospoides Hochenw.)

Addenda. Abbé J. J. Kieffer has characterized two genera not included in my genera of the Onychiinae, Psyche, vol. 10, p. I r. In order that these genera may not be overlooked I give below a revised table of the genera :-

\section{Table of Genera.}

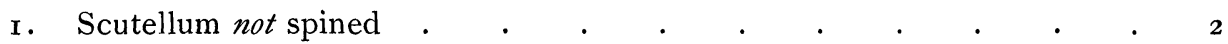

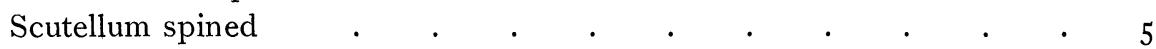

2. Marginal cell closed, more or less, at the base ; hind tibiae without longitudinal ridges . . . . . . . . . . . . . . . 3

Marginal cell open at the base and along the front margin; hind tibiae with

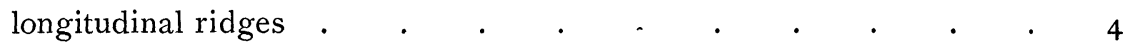

3. Mesonotum smooth, polished, with two distinct furrows, without carinae; scutellum without a median longitudinal carina; marginal cell closed along the front margin; petiole of abdomen smooth. . Homalaspis Giraud

Mesonotum scabrous, with three longitudinal carinae; scutellum with a median longitudinal carina ; marginal cell open along the front margin ; petiole of abdomen furrowed . . . . . . Lambertonia Kieffer

(Type L. abnormis Kieffer.)

4. Scutellum without a channel throughout and without transverse ridges

Tavaresia Kieffer (Type T. carinata Kieffer.) 
Scutellum with a deep channel throughout and with transverse ridges

Onychia Haliday

5. See my table from 2 for the other genera.

Abbé Kieffer in Wytsman's Genera Insectorum, Fam. Cynipidae, p. 9, has incorrectly included Solenaspis Ashm. with the Onychiinae; it is a genuine Figitine and not an Onychiine.

\section{SOME APHIDS ASSOCIATED WITH ANTS.}

BY WilMATTE PORTER COCKERELL, COLORADO SPRINGS, COL.

The species of Lasius which occur here attend both aphids and mealy bugs in large numbers and great variety. During the past two years my husband and I have made somewhat extended observations on the behavior of the ants toward their captives and upon the distribution both of the ants and their prisoners. We are indebted to Dr. Wm. M. Wheeler for the identification of the ants.

The species of ants studied make their nests under flat stones. In this climate the ants are active during the most of the winter, and live in the corridors under the stones, except in very severe weather, when they retire into their subterranean chambers carrying their aphids and coccids with them. In the long droughts to which this region is subject the ants are obliged in most places, to live far underground, and after such a siege the number of aphids and coccids is small. In the summer, which is the rainy season, the ants' nests are often greatly extended and large chambers are made about the roots of plants.

\section{FORDA KINGII, sp. nov.}

\& Body oval or ovate, gray drab to greenish with sutures inconspicuous. Head not distinct from the rest of the body; eyes small but distinct. The whole body including antennae is sparsely hairy. The cauda is a distinct rounded tail decidedly hairy on the end. Legs as in Tychea lasii.

Antennae five jointed, short, and slender; first and second joints subequal, third about three times as long as second, fourth about as long as second, fifth with a short cylindrical spur about one half the diameter of the segment and including spur only slightly longer than the fourth. Sensoria distinct. Length of antennal joints (I) 60 (2) 60 (3) I35 (4) 60 (5) $78+12 \mu$.

Haв. - Found in nests of Lasius claviger, L. flavus, Formica sp., L. americanus, at Lawrence, Mass., Andover, Mass., Methuen, Mass. Collected by Mr. George B. King who writes: "feed on roots of grass in ants' nests under stones ; young are brownish." 

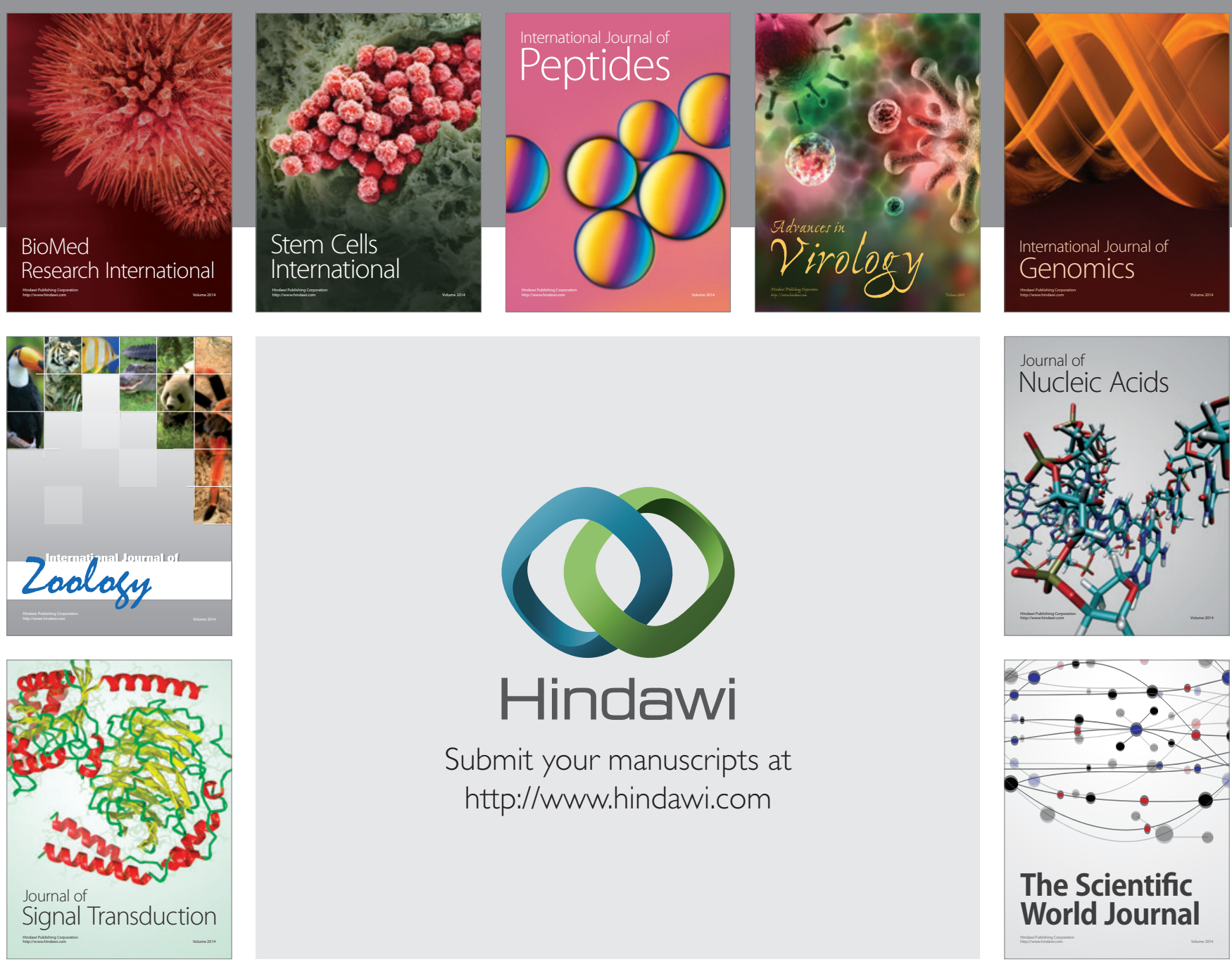

Submit your manuscripts at

http://www.hindawi.com
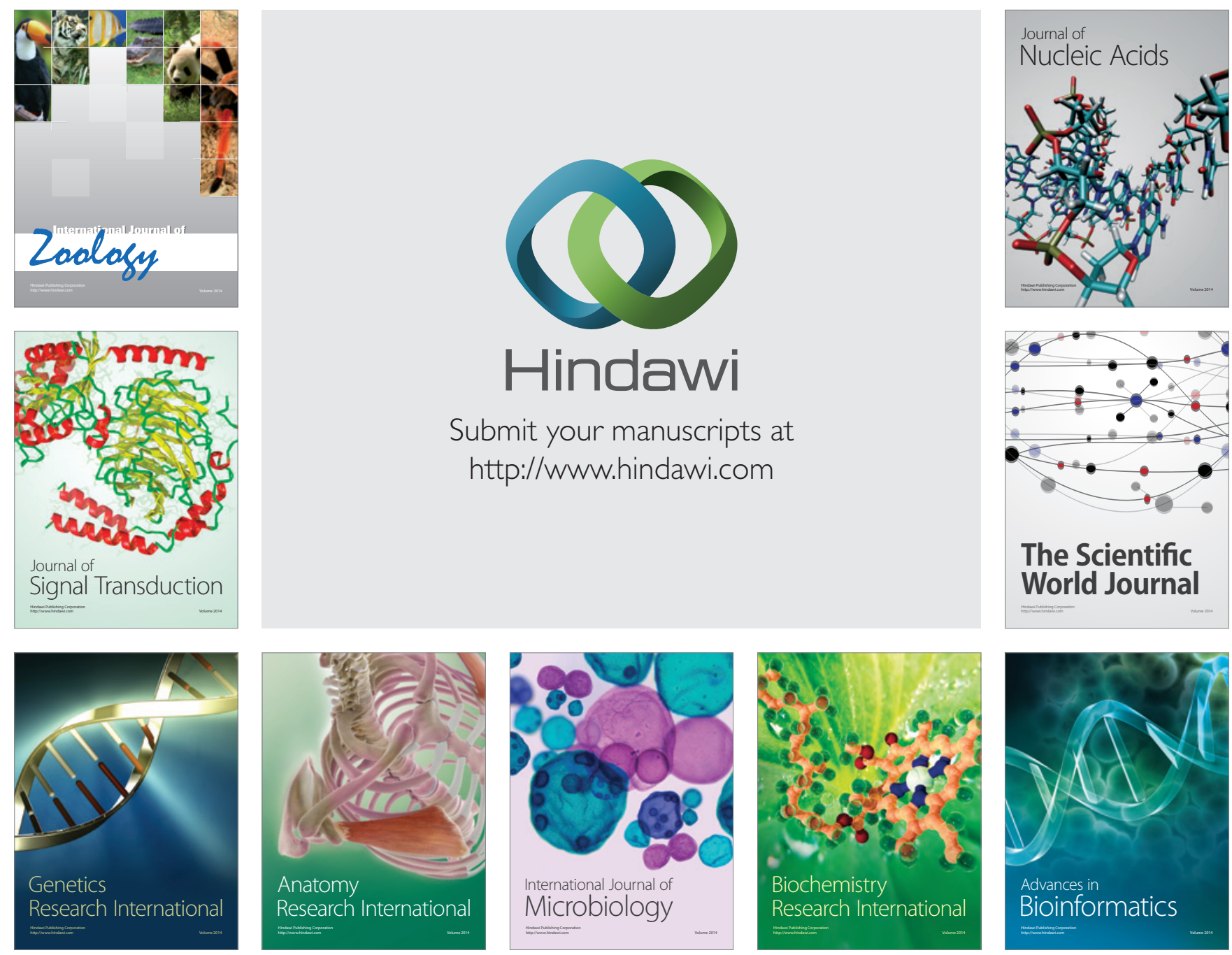

The Scientific World Journal
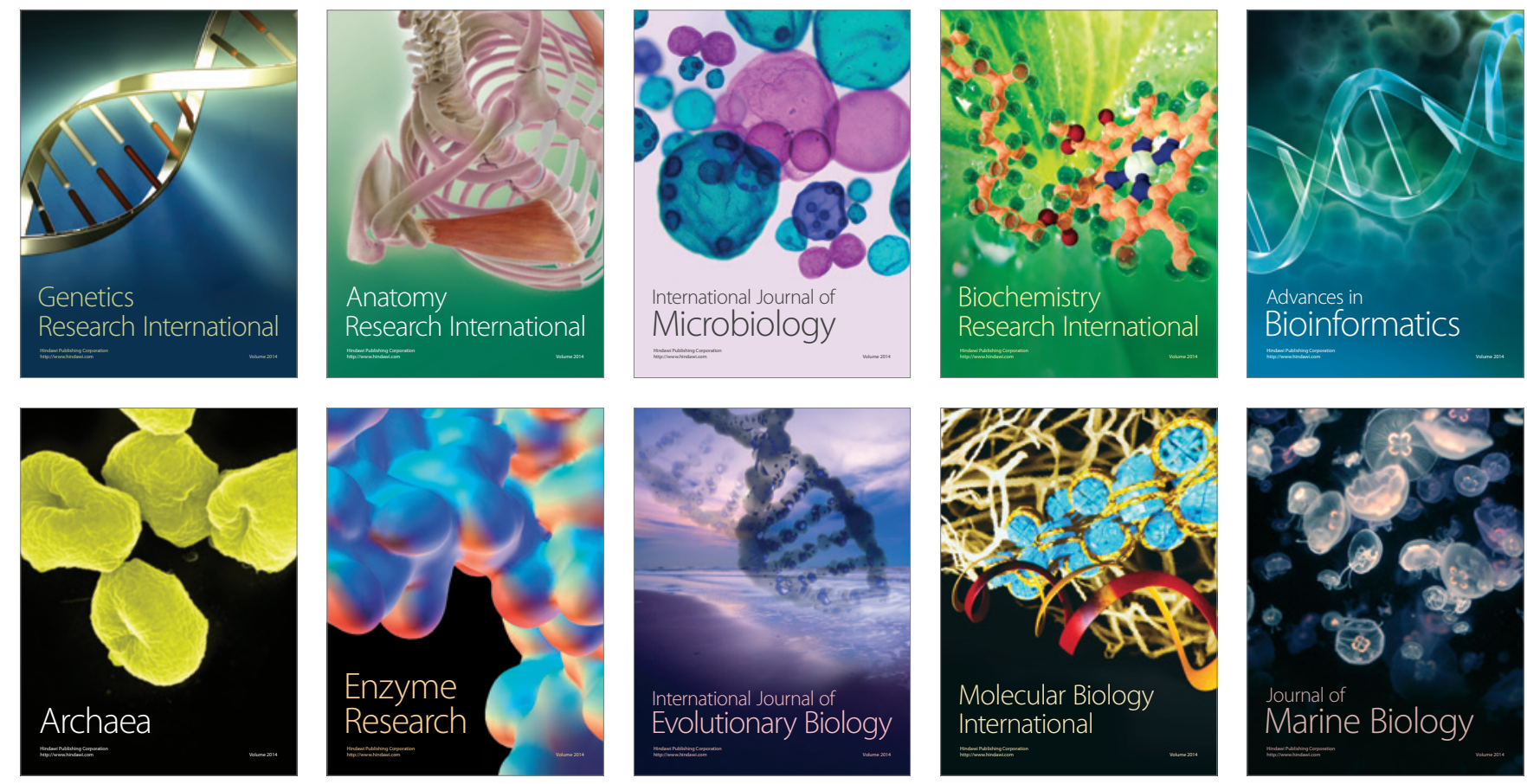